MileI ve Nihal, 13 (2), 2016

\title{
İbadet, Ritüel ve Kurban
}

Hakan OLGUN*

Worship, Ritual and Sacrifice

Citation/C: Olgun, Hakan, (2016). Worship, Ritual and Sacrifice, Milel ve Nihal, $13(2), 82-99$.

Abstract: In religion studies, special behaviors and actions that are performed with religious objectives are defined as 'worship'. In Paganist traditions, these actions and behaviors are expressed as 'ritual'. When these two concepts are compared from a formal point of view, both worship and ritual exhibit similar forms of behavior. However, there is a great difference on the spiritual level between the Islamic concept of worship and the ritualistic behavior of the paganist tradition. In ritualistic behavior, human being has a mechanical relationship with God and is concerned with obtaining benefits. While worship is defined as a lifelong commitment of a believer to God, that is backed by a servitude mindset and consciousness. Therefore, while ritual defines a relationship that is god-oriented, periodic and based on mutual interest, Islamic sense of worship expresses the consciousness of being a servant of the God by the believer, in the wake of the Hereafter.

Key Words: Worship, ritual, sacrifice, tragedy, Kierkegaard.

Atıf/C: Olgun, Hakan, (2016). İbadet, Ritüel ve Kurban, Milel ve Nihal, 13 (2), 82-99.

Öz: Dinsel amaçlarla yerine getirilen özel davranışlar din araştırmalarında "ibadet" olarak tanımlanır. Pagan gelenekler açısından bu tür davranışlar "ritüel" kelimesiyle ifade edilir. Şekilsel açıdan bu iki kavram kıyaslandığında ibadet ile ritüelin benzer davranış şekillerini yansıttığı görülür. Ancak İslami bir kavram olan ibadet ile paganist geleneeğin ürünü olan

* Prof. Dr., İstanbul Üniversitesi, İlahiyat Fakültesi, Dinler Tarihi Anabilim Dalı [holgun@istanbul.edu.tr] 
ritüelistik davranış arasında manevi düzlemde büyük bir farklııı söz konusudur. Ritüelistik davranışta insanın tanrı ile mekanik bir ilişkisi ve menfaat edinme kaygısı söz konusudur. İbadet ise mümin bireyin yaşamı boyunca sürdüreeceği rabbine karşı kulluk bilincinin bir parçası olarak anlam kazanmıştır. Dolayısıyla ritüel, tanrıya dönük, dönemsel ve karşılıklı çıkar ilişkisine dayalı bir ilişkiyi tanımlarken İslami anlamda ibadet ahiret saadeti peşindeki müminin rabbine kul olma bilincinin davranışa yansımış halini ifade etmektedir.

Anahtar Kelimeler: ibadet, ritüel, kurban, trajedi, Kierkegaard.

“Onların ne etleri, ne de kanları Allah'a ulaşır. Lâkin ona ulaşan tek şey, kalplerinizde beslediğiniz takvadır." (Hac: 37)

\section{Giriş}

Yeryüzünde varlık bulan bütün din ve inanç geleneklerinin itikat esaslarının yanı sıra dini amaçlı tutum ve davranış modellerine sahip olduğu bilinmektedir. Esasen modern din araştırmacılarının üzerinde mutabık olduğu en temel sorun, "din" kelimesine ait kesin bir tanımın yapılamamasıdır. Her bir dini geleneği diğerlerinden ayıran farklı ya da öne çıkan bir boyutu söz konusudur. Bununla birlikte çeşitli dini gelenekler üzerinde yapılmış olan bütün "din" tanımları dikkate alınarak hepsinin ortak vurguları çerçevesinde dinin üç temel unsuru öne çıkmaktadır: (i) İnanç; (ii) İbadet; (iii) Cemaat. Bu durumda bir dinin "din" olarak nitelenebilmesi için bu üç temel unsuru bünyesinde buluşturmuş olması gerekir. İnanç bir takım bedensel davranış modellerine kaynaklık ederken bu modellerin söz konusu inanca sahip kişiler tarafından ortaklaşa yapılıyor olması ibadet ve cemaat boyutunu ifade etmektedir. Söz konusu tanım bağlamında din tanımının bu temel unsurları sadece kitabi ya da kurumsal dinlerde değil pagan-politeist inançlar için de söz konusudur. İslam dinine münhasır Kur'anî bir kavram olan "ibadet" ile din araştırmalarının klasik bir kavramı olan "ritüel" çok kolayca ilişkilendirilmektedir. Bu çalışmada din tanımı içinde yer alan dinsel davranış ve ritüel boyut pagan-politeist inançlar bağlamında ele alınacaktır. Özellikle kanlı kurban takdimesi çerçevesinde ritüel ve ibadet kavramları değerlendirilecektir.

\section{Ritüel}

Batı dillerinde "ritüel" kelimesinin Latince'den kökünü oluşturan "rit" kelimesi "bir şey yapmak" anlamına gelmektedir. Kavram bi- 
raz daha özelleştirildiğinde, "inananların üzerinde uzlaşarak simgesel anlam yükledikleri geleneksel uygulamalar" olarak tanımlanmaktadır. Kavramın bu tanımıyla metafizik bir bilgi kaynağından çok o metafizik bilgiye iman etmiş kişilerle ilişkilendirildiği anlaşılmaktadır. Ayrıca ritüelin bu tanımına, uygun zamanlarda yerine getirilen ve sembollerin kullanılabildiği, sık sık tekrarlanan bir davranış modeli olduğu da eklenir. ${ }^{1}$ Yine ritüel kavramı, ritüeli icra eden kişiler tarafından dile getirilen anlaşılması güç söylemlerin ve birbiri ardına gelen ama hiç değişmeyen şekilsel davranışların temsilini ifade etmektedir. Temsili ve sembolik davranışlar, katı bir şekilsellik, kuralları belirli olan, uygulayıcısından başkası tarafından tam olarak anlaşılmayan terennüm özellikleri bütün ritüeller için genellikle ortaktır. ${ }^{2}$ Ritik davranışın sergilenmesi, kişinin bilinçli ve gönüllü olma durumunu içermektedir. Dolayısıyla ritüel, bilinçli bir şekilde oluşturulmuş, tekrarlanmaya uygun, biçimlendirilmiş sembolik ve bedensel davranışlardır. ${ }^{3}$ Ancak bu davranışlar mutlaka kendilerine mistik varlıkları ya da olağanüstü güç unsurlarını referans alır. ${ }^{4}$

Bu tanımlar şekilsel, belirli bir üsluba dayalı ve tekrarlanan davranışlar, ayrıca olağanüstü kudretlerle ya da en azından kozmik yapıyla bağlantılı bir uygulama serisini içermektedir. Bu sayılanlar ritüelin temel unsurlarını ifade etmektedir ancak yine de genel kabulün sağlandığı bir ritüel tanımı yapmak zordur. Bununla birlikte ritüel kavramı aşağıdaki hususiyetlere sahip bir fenomen olarak karşımıza çıkmaktadır:

(i) Ritüel bedensel bir davranış olarak şekillendirilmiştir. Ritüelin en belirgin özelliği insani bir eylem olmasıdır. İnsanlar bu eylemi aleni olarak bedensel bir tarzda yapmaktadır. Ancak ritüel sadece zihinde ya da hayal gücünde var olmuş değildir; hem bilinçsel hem de temsilidir. Eğer bir davranış bütünüyle zihinsel ise bu davranış ritüel sayılmaz. Aynı

1 "Ritual", A Dictionary of Sociology, ed.: J. Scott, G. Marshall (Oxford: Oxford University Press, 2009), s. 653.

${ }^{2}$ Ray A. Rappaport, Ritual and Religion in the Making of Humanity (Cambridge: Cambridge University Press, 1999)

${ }^{3}$ E. M. Zuesse, "Ritual", Encyclopedia of Religion (New York: Macmillan, 1987), 12, s. 405.

4 Victor Turner, Forest of Symbol (Ithaca: Cornell University Press, 1967), s. 19. 
zamanda bir takım hatıralara ya da fantezilere dayalı davranışlar da ritüel sayılmaz.

(ii) Ritüel, zihinsel bir yoğunlaşmayı gerektirir. Ritüel davranış, sıradan insani bir hareket gibi gözlenmesine rağmen olağan dışı bir davranıştır. Bu yüzden ritüel, gündelik davranışa göre daha yoğun ve derin bir bilinç içinde sergilenir, sıradanlık ve aleladelikten farklı bir temele dayanır. Ritüel, sıkça tekrarlanması açısından bir olağanlık görünümünde olsa da onu sıradan davranıştan ayıran yönü olağanüstü ile olan bağlantısıdır.

(iii) Ritüel katı kurallarla belirlenmiştir. Bireysel ya da bir dini öncü liderliğinde topluca yapılmış olsa dahi ritüel öncesi hazırlıklar, ritüelin gerçekleştirilmesi ve sonlandırılması gibi üç aşama kesin kurallarla belirlenmiştir. Bu temel kurallara uyulmadığ zaman ritüel bozulmuş sayılır ve en başa dönülerek kurallara uygun bir şekilde yeniden sergilenir.

(iv) Ritüel, bilinç düzeyinde yer alan düşüncenin bütünüyle davranışlara aktarılma çabasını içerir. Bu yönüyle ritüel davranış sahnelenmeye uygun bir performans gibi de değerlendirilebilir. Ritüel esnasında dile getirilen sözler de aynı şekilde sahne sunumunda dile getirilen tiratlar gibi etkileyici, ürkütücü ve çoğunlukla da anlaşılmazdır.

(v) Ritüeller sürekli tekrarlanan davranışlardır. Tekrarlanmaya uygun olarak biçimlendirilmişlerdir ve her vesileyle tekrar sahnelenir. Günlük ritüeller, mevsimlik ritüeller ve yıllık ritüeller, bazen tarımsal gerekçelerle, bazen av bereketi için bazen de doğum, ölüm ve hastalık gibi durumlarda her daim aynı ritüelin tekrarı mümkündür.

Yukarıdaki tespitler "ritüel" kavramını bütünüyle kuşatan bir tanımın yapılmasının güçlüğünü ifade etmektedir. Bununla birlikte aynı tespitler çerçevesinde ritüelin olağanüstü ile temas anını ifade eden, katı kurallarla sabitlenmiş, sıklıkla tekrarlanan ve kendine has, yani ritüel kültün dışındaki kişilerce kavranamayan, perfor- 
mansa dayalı dinsel davranış modeli olarak tanımlandığı görülmektedir. Esasen din araştırmacılarının ritüel tanımı yaparken üzerinde mutabık kaldıkları ritüele dair temel özellikler de bunlardır.

Ritüel ile İslami kavram olan ibadet arasındaki ayrıma işaret etmek için ritüelin özellikle paganist geleneklerindeki görünümünü tespit etmek gerekir. Pagan toplumlarda ritüel davranış ve dinsel törenlerin en yaygını, tanrılara kurban sunumu olarak kendini göstermektedir. Kurban sunumu, pek çok din ve inanç geleneğinde yoğun olarak sergilenen bir davranış olarak hem ritüel hem ibadet kavramının sınırlarını çizen veriler sunmaktadır.

\section{Bir ritüel örneği: kadim Yunan geleneğinde kurban}

Pagan toplumun ritüel uygulamaları konusunda kadim Yunan ve Roma geleneklerinde sergilenmiş olan kurban ritüeli pek çok açıdan ele aldığımız konuyu izah edecek bir modeldir. Yunan geleneğinde kurban anlatısı, bu geleneğin en eski kaynağı olan Homer' in Odessey destanında öykülenmiştir. Yunan mitolojisine göre Yunan ordusunun danışmanı olan Nestor, tanrıça Athena'ya bir kurban sunmaya niyetlenir. Destandaki anlatı, ritüelin yukarıda bahsedilen üç aşamada gerçekleştirildiğini ifade etmektedir: ritüele hazırlık; ritüeli icra ve ritüeli sonlandırma. Kurban ritüeline hazırlık safhasında, usulüne uygun olarak seçilen kurban edilecek boğanın boynuzları altın folyo ile kapatılıp Nestor'un iki oğlu tarafından boynuzlarından tutulup adeta sürüklenerek ritüel ortamına getirilir. Sürahi içindeki temizlenme suyu, balta ve boğanın kanının toplanacağı kâselerin yanında alevli bir ateş de yanmaktadır. Nestor önce boğanın saçlarından bir tutam keserek ateşe atar. Böylece ritüelin ikinci aşaması, yani icra safhasına geçilmiş olur. Bu sırada ritüele dâhil olan herkes tanrıça Athena'ya kurban sunumuna ilişkin dualar okumaktadır. Nestor'un bir oğlu boğanın boynundaki tendonlardan birisini keser; bu sırada acı çeken hayvanın sesini bastırmak için duaların ses tonu artırılır ve bu durum oradakiler tarafından çığlıklarla karşılanır. Daha sonra boğa Nestor'un iki oğlu tarafından boğazlanır ve uzuvları kesilerek parçalara ayrılır. Hayvanın yağı ile sarmalanmış iç organlar ateşe atılıp yakılır ve etrafı kesif bir koku ve dumanın sarması hedeflenir. Ritüelin sonunda kurban edilen bo- 
ğanın diğer parçaları Nestor ve ailesi tarafından bir yemek öğününde tüketilir. Böylece kurban sunu ritüelinin sonuna gelinmiş olur. ${ }^{5}$

Geleneksel olarak tanrılara sunulacak olan kurbanlık hayvan ritüelistik bir süreç içinde ve üç safhalık bir uygulama içinde kurban edilir: Hazırlayıcı sözlerle ritüele hazırlık; hayvanı kesme ve kurbanı bu âlemden ilahi âleme ulaştırma; son olarak kurban ritüelini sona erdiren kutsal öğün. ${ }^{6}$ Kurban ritüeline mutlaka duaların eşlik etmesi gerekmektedir. Duasız kurbanın tanrılardan beklenen faydayı hâsıl ettirmeyeceğine inanılır.7 Paganist gelenekte kurban edilecek hayvanların cins ve özellikleri de katı kurallara bağlıdır. Örneğin yaban hayvanları ve balıklar kurban olarak kullanılmaz. Roma geleneğinde ayrıca erkek hayvanlar tanrılara, dişi hayvanlar tanrıçalara kurban sunulur. Juno ve Jupiter'e sunulan kurbanın rengi beyaz, yer âleminin tanrısına sunulan kurban ise siyah olur. Yunan-Roman geleneğine göre kurban ritüelini bitiren ve kurban edilen hayvanın etinin yenildiği toplu yemeğin aynı zamanda tanrılar düzeyinde de yenildiğine inanılır. Fakat tanrıların kurban hayvanının etini tüketmesi mezbahta yakılmış olan kurban etinin aromatik dumanın göklere ulaşmasıyla gerçekleşir. ${ }^{8}$

Yunan-Roma geleneğindeki kurban ritüelinde sadece hayvanların değil ritüele katılacak olan insanların da sosyal statü ve cinsiyetlerine göre hiyerarşik bir farklılaşma halinde olmuştur. Her ne kadar bu gelenekte kurban ritüelleri toplumun bir arada yemek yemelerine vesile olsa da bu toplum içindeki sınıf farklılaşmasını ortadan kaldırmamıştır. Farklı hiyerarşi ve statüdeki kişiler kurban ritüelinin farklı evrelerinde iş görmüşlerdir. Örneğin bazıları kurban ritüelinin icrasından, bazıları etin paylaştırılmasından, bazılariysa alt sınıf üyelerinin ritüel ortamından uzak tutulmasından

\footnotetext{
${ }^{5}$ Bkz. Jan N. Bremmer, Greek Normative Animal Sacrifice, A Companion to Greek Religion, ed.: D. Ogden (Oxford: Blackwell, 2007), s. 133.

${ }^{6}$ R. M. Ogilvie, The Romans and their Gods (London: Hogarth Press, 1986) ss. 4152.

${ }^{7}$ Bkz. Ingvild Sælid Gilhus, Animals, Gods and Humans (London: Roudletge, 2006), s. 115.

${ }^{8}$ Detienne, M. and J.-P. Vernant (eds), The Cuisine of Sacrifice among the Greeks (Chicago: University of Chicago Press, 1989), ss. 1-20.
} 
sorumlu olmuşlardır. 9 Toplumsal tabakalaşmanın alt sırasında bulunan kişiler ise kurbanlık hayvanı sürükleyerek ritüel mekanına getirilmesi, hayvanın öldürülmesi, kanının akıtılması ve iç organlarının incelenmesinden sorumludur. Bu işlerin çoğunu yapmaktan sorumlu olan kişi elindeki baltayla grup içinde kolayca görünür. Hayvanın kanının akıtılarak öldürülmesi sırasında çıkardığı sesi bastırmak için de bir kişi özel olarak flüt çalar. Ancak flüt çalan kişinin ve dua eden rahibin dişında herkes büyük bir sessizlik içindedir. Esasen bu kurban ritüelini yönetenler rahipler olurken ritüelin görsel bir etkinliğe dönüşmesinin asıl sorumluları yardımcı ve hizmetlilerdir. Kurban edilen hayvanın etlerinin katılımcılar arasında paylaştırılması ise ritüelinin sonunu ilan etmiştir. Yunan kurban geleneğinin merkezinde, kurban edilen hayvanın etlerinin ritüele katılanlar tarafından yenilmesi, hayvanın kendi yağı ile sarmalanmış iç organlarının ise mezbah üzerinde yakılarak dumanın tanrıya ulaştırılması vardır..$^{10}$

Bu ritüelin yürütülmesi sırasında en önemli husus, ritüele katılan kimselerin kesinlikle bir hata ve yanlışlık ya da kirlilik durumu içinde olmamalarıdır. Aksi halde tanrılar buna kızacak ve tanrılar ile insanlar arasındaki iyi ilişki bozulacaktır. Bu ilişkinin barış içinde sürdürülebilmesi için kir ve hatalardan arınmış şekilde tanrılara kurban sunulmalıdır. ${ }^{11}$ Ritüeli hatasız ve usulünce yapma zorunluluğunun gerekçesi olan tanrıları kızdırmaktan ya da onlarla insanlar arasındaki barış ortamını bozmaktan kaçınmak, paganist kurban ritüelinin sebebini de ortaya koymaktadır. Dolayısıyla pagan toplumlarda icra edilen kurban ritüeli öncelikle tanrıları teskin etme, sakinleştirme, insanlara karşı cömertliklerini elde etme sebebine yöneliktir. Ancak bu durum pek çok din araştırması için bir trajedi kaynağı olarak görülmüştür.

\footnotetext{
${ }^{9}$ Ingvild Sælid Gilhus, Animals, Gods and Humans (London: Roudletge, 2006), s. 116.

${ }^{10}$ P. Garnsey, Food and Society in Classical Antiquity (Cambridge: Cambridge University Press, 1999), s. 134.

${ }^{11}$ Ingvild Sælid Gilhus, Animals, Gods and Humans (London: Roudletge, 2006), s. 116.
} 


\section{Kurban ve trajedi}

Kadim Yunan edebiyat geleneğinin en temel unsurlarından olan trajedi ile ritüel arasında çok yakın bir ilişki kurmak mümkündür. Köken itibarıly tragos "oğlak", oidia "şarkı" anlamına gelmekte ve "trajedi" kelimesi "oğlağın şarkısı"nı ifade etmektedir. Çünkü pek çok pagan Yunan ritüelinde oğlak en önemli kurban hayvanı olarak boğazlanmıştır. ${ }^{12}$ Dolayısıyla, bu ayrıntı bir yana, trajedi ile kurban ritüeli arasında yakın bir ilişki söz konusudur. Trajedi aynı zamanda kadim kültürel davranışları ve pagan ritüellerin performansını ifade eden bir sahne oyunudur. Konularını genellikle ritüelistik sunumlar içinde sergiler. Örneğin XX. yüzyılın sonlarına doğru yeniden yaygınlaşan tiyatro oyunları, "ritüelin geri dönüşü" olarak kutlanmıştır. ${ }^{13}$

Kurban, aynı zamanda Yunan geleneğinin köklü metinlerinden olan Homerik destanlarda önemli bir rol oynar. Yukarıda kısaca ifade edildiği gibi, Homeros'un destanındaki kurban sahnesinin Yunan sahne kültüründe yer alan trajedilerden birisi olduğu artık yaygin bir kanaattir. Bu kanaat, esasen dini gerekçelerle kurban kesen kişilere dönük seküler aşağılamacılığın da kaynağını oluşturur. Bu kanaati savunanların öncüsü W. Burkert'a göre din, hayatın yayılması ve sürdürülmesiyle yani üremeyle ilişkilidir. Ancak dinler varlıklarını yaşamla gösterir gibi yaparken derinlemesine bir ölüm telkini halindedirler. Dolayssıyla Burkert kurban ritüeli nedeniyle dini, ölümle, özellikle de öldürme ile ilişkilendirmiştir. Yunan trajedisi ve kurban ritüeli konusunu işlediği metninde Burkert, bir küçükbaş hayvan kurban etme geleneğinin kişiyi tarih öncesi insani gelişimin derinliklerine nasıl geri götürdügüne işaret etmek istemiştir. Ona göre öldürmenin korkusu ve kan akıtmanın histerik telaşı, yaşam ve ölümün çift yönlü veçhesinde kurban ritüeli ile insan varlığının köklerine dokunmak demektir. ${ }^{14}$ Bu düşüncede işaret edilen husus, dinin kaynağının tanrıya kurban sunumu sırasındaki duygusal durum ile yakın bir ilişki olduğu iddiasıdır.

${ }^{12}$ Kevin J. Wetmore, Jr., The Athenian Sun in an African Sky: Modern African Adaptations of Classical Greek Tragedy (London: McFarland \& Company, 2002), s. 62.

${ }^{13}$ Sarah Dewar-Watson, Tragedy: A Reader's Guide to Essential Criticism (London: Palgrave Macmillan, 2014), s. 8.

${ }_{14}$ Walter Burkert, Greek Tragedy and Sacrificial Ritual (Duke University, 1966), ss. 113-121. 
Burkert'ın iddiaları dinin kaynağını araştıran Taylor, Spencer ve Frazer gibi Viktoryan düşünürlerin tezleri açısından sıra dışı idi ve onların tezlerini yeniden değerlendirmiştir. Nitekim Burkert dinin kaynaklığıyla ilgili olarak, adı geçen din araştırmacılarından farklı şekilde, kurban ritüelinden türemiş bir dinden söz etmekteydi. Böylece o, insanın dini yaşamının kaynağına kurban ritüelini koymuş ve kurban ritüelinden önce bir dinin varlığından söz edilemeyeceğine işaret etmiştir. Bu yaklaşıma göre dini anlamak için öncelikle kurbanı anlamak gerekir ya da aslında kurbanı anlamak dini anlamaktır. ${ }^{15}$

Yukarıda ifade edildiği gibi Burkert da trajediyi "oğlağın şarkısı" ya da daha doğrusu "ağıdı" olarak tanımlar. Esasen bu ifade, kurban edilen hayvanı insanlığın üzerinde geliştiği en temel unsur olarak nitelerken, ilkel olanı ise yüceltilmiş edebi ilerlemelerin kurucu temeli olarak tanımlar. ${ }^{16}$ Dolayısıyla insanlığın sosyal gelişim ve ilerlemesi bir anlamda hayvan kurbanı ritüeli bağlamında tanrısal unsurlarla kurulan temas tecrübesine dayanmaktadır. Aslında içinde bulunulan durum, yaşama duyulan saygı ile öldürme emri arasındaki gidiş-geliş halidir. Öldürme ritüelinin trajik jestleri toplumu ortak suç etrafında bir araya getirir. Bu anlayışa göre bir kurban ritüelinde toplum, sosyal birlik olarak ortak şok ve suç duygusu içinde birbirine bağlanır. ${ }^{17}$

Kurbanın bir trajedi olması, esas itibarıla pagan tanrı tasavvuru ve bu tanrıyı razı etmeye dönük arayışın bir uzantısıdır. Tanrı veya tanrilara, onlardan gelecek afet, felaket, kitlık ve belalardan emin olmak için teskin edici ritüellerin sergilenmesi gerektiği düşünülmüş olmalıdır. Kurban ritüelinde tanrıları teskin eden unsur, hayvanın yağına sarılmış iç organlarının ateşe atılmasıyla yükselen yanmış et, yağ ve sakatat kokusudur. Duman duman göğe doğru yükselen bu kesif kokunun tanrıların gazabını engelleyecek şekilde onları tatmin ve teskin ettiği düşünülmüştür. Böylece insan varlığ1nın tanrının gazabından emin olacağına ve ondan beklediği ilahi yardım ve desteği elde edeceğine inanılmıştır. Burkert'ın bahsettiği

${ }^{15}$ Understanding Religious Sacrifice: A Reader, ed.: J. Carter (London: Continuum, 2006), s. 210

${ }^{16}$ Walter Burkert, "Ritual in Ancient Greece", Savage Energies: Lessons of Myth and Ritual in Ancient Greece, tr. P. Bing (Chicago: University of Chicago Press, 2001), s. 2 .

17 Burkert, "Ritual in Ancient Greece”, ss. 13, 15. 
trajik nokta burada ortaya çıkmaktadır. Tanrılar yanık et kokusuyla teskin olmakta ve bunun için insanlardan kendisi için canlı bir hayvanı öldürüp ateşte yakarak sunmasını istemektedir. Tanrıların bu kokuyla tatmin olmaları Burkert için işin acı tarafını oluşturmaktadır. Asıl trajedi ise böylesi bir inanca sahip olmakla başlamaktadır. Dolayısıyla tanrıların bu şekilde teskin edilip yatıştırıldığına inananların katı bir ritüelistik uygulamalar ile canlı bir hayvanı boğazlamaları ve ateşte yakmaları bu acının trajediye dönüşen tarafıdır. Kaldı ki Burkert, dinin kökeni ile kurban arasında bağlantı kurarken, tanrıların kurban istediği inancının yani acı veren bir talebin bir trajediye dönüşmesini bu dinin insan belleğinin ürünü olduğu sonucuyla ilişkilendirmektedir.

Paganist ritüellerin yol açtığı bazı trajik örnekler Cahiliye Arap toplumunda da yaşanmıştır. Hz. Peygamberin dedesi Abdulmuttalip on erkek çocuğu olursa birisini tanriya kurban edeceğine söz verir. Nihayet erkek çocuklarının sayısı onu bulduğunda hangi çocuğunun kurban edileceğine kakar vermek üzere Hübel'in önünde fal oku çekilir. Çekilen ok Hz. Peygamberin babası Abdullah'1 işaret ettiğinde her çekilen ok için on deve bedel konularak Abdullah ile develer arasında kura çekimine devam edilir. Develerin sayısı yüzü bulunca fal okları nihayet develeri işaret eder. Cahiliye döneminin paganist geleneği, batıl bir şekilde Abdullah'ın kurban edilmesini gerektirmiştir. Aynı gelenek Abdullah'a karşılık yüz devenin bedel tutulmasını işaret etmiştir. Tüm bu ritüellere Hübel putu şahit tutulmuştur. Burada Burkert düşüncesine göre fal oku çekmek suretiyle tanrıların kanaatini öğrenme ya da değiştirmenin mümkün olacağı inancı insan benliğini inciten ve ona acı veren bir inançtır. Ancak bu inancın gereğinin yapılması Abdulmuttalip için bir trajediye dönüşmüştür.

\section{Kurban ve diyalektik lirik}

Kurban ritüeli mitolojik anlatıların ve kadim pagan geleneklerinin yanı sıra Yahudi kutsal metninde de yoğun olarak işlenmiş bir anlatıdır. Yahudi kutsal metni kurban anlatısını Hz. İbrahim ve kurban edilmesi istenen oğul Hz. İshak üzerinden yürütmektedir.

Daha sonra Tanrı İbrahim'i sınadı. “İbrahim!" diye seslendi. İbrahim, “Buradayım!" dedi. Tanrı, "İshak'ı, sevdiğin biricik oğlunu al, Moriah bölgesine git!" dedi, "orada 
sana göstereceğim bir dağda oğlunu yakmalık sunu olarak sun" (Tek. 22:1-2)

Yahudi kutsal metnindeki kurban anlatısı Hz. İbrahim'e dönük bu çağrıyla başlamakta ve Hz. İbrahim'in oğlu İshak, odun taşıyan eşeği ve hizmetçileri ile üç günlük Moriah yolculuğu ile devam etmektedir. Moriah dağı karşıdan göründüğünde Hz. İbrahim hizmetçilerini geride bırakarak İshak ile tepeye çıktıklarında İbrahim İshak'1 yüzüstü yatırır. Ancak İshak'1 boğazlayacak iken Rab ona imtihanı kazandığını söyler ve gönderdiği koçu İshak'ın yerine kurban etmesini ister.

Meselenin izahı insan zihninde kutsal metinlerde ifade edildiği gibi bir çırpıda ve kolayca yerleşmiş değildir. Hz. İbrahim'in Moriah dağına çıkarken hissettiklerini, oğlunun babasından endişe etmesini, Hz. İbrahim'in ilahi emrin oğlunu hedefleyen yönünü nasıl gözden geçirdiğini bilmiyoruz. Peygamber, yani rab ile vahyi temas halinde olan bir insan söz konusu olunca, İslam geleneğinde kişinin vahyi emirle temas halinde neler hissettiği sorgulanmaz. Ancak Hz. İbrahim' in Kitab-1 Mukaddes anlatısına göre oğlu İshak' 1 kurban etmekle emrolunup kendisine İshak'ın yerine bir koçun verilmesine kadar neler hissetmiş olabileceği Soren Kierkegaard'in Korku ve Titreme kitabına konu olmuştur. ${ }^{18}$

Geleneksel Hıristiyan düşüncesini zaman zaman eleştirse de Kierkegaard katı bir Hıristiyan ortamında yetişmiştir. Onun, kendi dinsel geleneği içinde kurban ritüelini benzeştirebileceği bir model vardır: Komünyon ya da ekmek-şarap ayini. Hıristiyan ilahiyatına göre İsa Mesih insanlığın günahı adına çarmıhta öldürülüp kanı akıtılmıştır. Yani İsa Mesih ilk günahın sahibi Âdem'in ve insanoğlunun günahkârlığı adına, kefaret olarak sunulmuş bir kurbandır. M. S. 2. yüzyıl ve sonrasında etkili olan Hıristiyan teologu Marcion'un tespitiyle, Yahudiliğin ceberut ve yargılayıcı tanrısını Hıristiyanl1ğın sevgi ve merhamet tanrısına dönüştüren bu kefaret tecrübesidir. Buna göre Tanrı, insanoğlundan ilk günahın bedelinin ödenmesini ve kendisini teskin edecek bir kefaretin, yani kurbanın sunulmasını beklemektedir. İsa Mesih, Âdem'in günahının bedelinin ödetildiği bir sunudur ve bu yüzden Hiristiyan sembolizminde " kurbanlık

18 Soren Kierkegaard, Korku ve Titreme, tr. İ. Kapaklıkaya (İstanbul: Anka, 2002). 
kuzu" olarak resmedilmiştir. Her Pazar günü tekrarlanan Komünyon ayini, esasen İsa Mesih'in Tanrı'nın öfkesini yatıştırıp merhametine gerekçe olması için kurban olarak rabbe sunulmasının tiyatral ifadesidir.

Hıristiyan ilahiyatında komünyon ayininin bir kurban ritüeli olarak Yunan mitoloji geleneği ile sıkı bağlantısı kolayca fark edilmektedir. Burkert gibi antropologların savunduğu şekilde, Kitab-1 Mukaddes' in Tanrısı ancak İsa Mesih'in kanının akıtılmasıyla merhamet ve bağışlamaya taalluk eden sıfatlarını harekete geçirmiştir. Tanrı, İsa Mesih'in günaha bedel olarak ve başkasının, yani insanoğlunun yerine kurban edilerek ilahi adaleti yerine getirmiştir. Bu ritüel bir anlamda Eski Ahit'in yargılayıcı Tanrısı'nı Yeni Ahit'in merhametli Tanrısı'na dönüştüren bir sır (sakrament) olarak görülmüştür. Mutlak bilgi ve kudret sahibi olan Tanrı'nın kendi gazabının yatıştırılması için İsa Mesih yerine niçin örneğin bir ağaç kütüğünü bedel olarak saymadığ 1 Hıristiyan ilahiyatında çokça tartışılmıştır. Belli ki bazı Hıristiyan teologlar Yunan pagan geleneğindeki kurbanın trajik etkisini hafifletmek istemişlerdir.

Komünyon ayininin, ritüelin kaçınılmaz trajik anlamıla tecrübe edildiği böylesi bir dini gelenek içinde yetişen Kirkeegard'ın Korku ve Titreme'sinde İbrahim peygamberin, oğlu İshak'ı kurban edişi öncesinde yaşayabileceği psikolojik savrulmaların tespitine çalışılmıştır. Kirkeegard kısa metninde, iman ve ahlak bağlamında temel olarak üç probleme yoğunlaşmıştır: (i) Etik olanın teolojik olarak askıya alınması söz konusu olabilir mi? (ii) Tanrı'ya karşı mutlak bir görevden sorumlu olunabilir mi? (iii) İbrahim oğlunu kurban edeceğini karısı Sara'dan, hizmetçilerinden ve İshak'tan saklaması etik midir? Her biri bir prensip ihtiva eden bu üç şüphe problem olarak ele alınmakta ve bunlar düzenli olarak Korku ve Titreme'nin diyalektik kısmını oluşturmaktadırlar. Ancak Burkert'ın acı ve trajedi bağlamıyla değerlendirdiği pagan kurban ritüeli perspektifinden bakıldığında Kirkeegard'ın ritüelin acı olan kısmına boyun eğen ama kurbanın trajik boyutunun ortadan kalktığına işaret eden bir yaklaşımı vardır.

Kierkegaard, Hz. İbrahim'in kurban anlatısı üzerinden esasen iman ve ahlak konularını tartışmaya açmakta ve bunları Hz. İbrahim'in oğlunu kurban etme yükümlülüğüne iman ya da bu yükümlülük sürecini gerçekleştirirken izlemesi gereken ahlaki yol 
bağlamında ele almaktadır. Düşünüre göre İbrahim, iman sınavında çektiklerinden dolayı yücedir. Dolayısıyla İbrahim'in bu öyküsüyle okuyucu ıstırabın doğasına odaklandırılmaktadır. Bu odaklanış rabbin kendisinden çocuğunu kurban etmesini isteyişidir. Kadim Yunan-Roma geleneğinin kurban ritüeli ile karşılaştırıldığında, İbrahim kıssasında da aynı acı verici kaynakla yüzleşilmiş olmaktadır. Pagan gelenekte insanlar, tanrıların gazabından emin olmak, felaketlerden uzak durmak ve bereketli bir tarım dönemi yaşamak, yani tanrılarla barış halini sürdürmek ve onları teskin etmek için hayvanları kurban ederlerdi. İşin acı tarafı, insanların huzur ve mutluluğu adına bir hayvanın, yani "günah keçisi"nin gözden çıkarılması ve tanrıların da bu sunudan mutmain olmasıdır. Metafizik âlemden fizik dünyaya egemen olan böylesi kudretli tanrısal unsurların bir hayvanın etinin yanık kokusu ile mutmain olması, modern perspektiften bakıldığında, acı bir durumu ifade etmiş olmalıdır. Kurban ritüelinin gerçekleştirilmesi süreci ise daha önce ifade edildiği gibi, acı verici bu ilişkinin trajik boyutunu ifade etmektedir. Kurbanın boyun tendonları ve şah damarı kesilerek akıtılan kanın kâsede toplanması ve kendi yağına sarılmış iç organların ateşin üzerinde dumanlanarak göklere ulaşması ritüel niyetiyle bir trajedinin sahnelenmesidir.

Hz. İbrahim'in rabbin isteği karşısında yükümlendiği zorlu süreci yürütebilmesi için birkaç yol izleme ihtimalinden söz edilmiştir. Örneğin, İbrahim rabbin kendisini kurban etme emrinin İshak'ın imanını zedeleyeceği korkusuyla kendi babalık değerini feda etmiş olabilir. İshak'a aslında bunun tanrının emriyle değil babası zannettiği ve aslında babası olmadığı kişi olarak kendi kararı şeklinde sunmuş olabilir. Bu durumda oğlunun gözünde kendi babalık değerini kaybedecek ama oğlunun rabbe dönük inancını koruyabilecektir. Ya da İbrahim oğlunun Moriah dağına götürüp kurban etmek üzereyken rabbin gönderdiği kurbanlık hayvan nedeniyle bu girişimini sona erdirecektir. Ancak İbrahim, gerçekleştirilmemiş olsa da yarım kalmış bu girişimin yüklediği travma hali içinde neden tanrının böylesi bir imtihanda bulunduğunu sorgulamış olabilir. Veya İshak, babasının kendisini kurban etmeye giriştiğinde bıçağı tutan sağ eli bir yana sol elinin umutsuzca sıkılmış olduğunu görmüş ve imtihanı yerine getirmenin insanın omuzuna yüklediği ağır yükü keşfetmiş olabilir. Bu yüzden İshak imanını yitirmiş olabilir miydi? 
Sorduğu bu sorularla Hıristiyan düşüncesi bağlamında imanın akıl düzleminde anlaşılamayacağını telkin etmiş olsa da esasen Kierkegaard, kurban ritüelinin acı veren gerekçesinin trajik bir sonuca dönüşmeden nasıl sonlandığını kavrama çabasındadır. Eğer Hz. İbrahim'in oğlunu kurban etmesi ile sonuçlanan bir ritüel süreci yaşanmış olsaydı, bu durum Hiristiyan komünyon ayininde İsa Mesih'in bir kurban olarak sunulması düşüncesine uygun olduğundan yadırganmayacaktı. Yine de Kierkegaard'a göre İbrahim' in eylemini yücelten şey, bu eylemi yaparken istırap çekmesidir. Yani kurban ritüelinin paganist gelenekteki acı verici gerekçesinin İbrahim için de bir acı kaynağı olduğu ifade edilmektedir. Bu durumda İbrahim, rabbin, kendi çocuğunu neden kendisine kurban etmesini emrettiğini sorgulamış olmalıdır. Zaten Korku ve Titreme' de tasarlanan mizansen anlatım bu hususu ortaya koymaktadır. Hıristiyan gelenekten gelen Kierkegaard, Tanrı'yı gazaplı halinden (Yahova) merhametli ve bağışlayıcı bir hale (Baba) çeviren kurban ritüelinin anlamının farkındadır. Esasen paganist kurban ritüelinin etkisini hissettiren bu uygulamaya göre Kierkegaard, İbrahim'in kurbanı tecrübesinde meselenin acı veren boyutunu keşfetmiş ancak sürecin bir trajediye dönüşmeden sonuçlanmasını neye yoracağını tasarlamıştır. Bu çerçevede meseleyi İbrahim'in imanı olarak ele almış görünse de Kierkegaard aslında bir babanın kendi eliyle ve rabbin emriyle oğlunu kurban etme girişimine ait senaryoyu trajedi boyutuyla sürdürmüştür.

\section{İbadet}

Ritüelin, gündelik yaşam içinde bireysel ya da topluca yapılan, kesin kuralları olan, sıklıkla tekrarlanan, kaynağı itibarıyla genellikle mitolojik bir anlatıya dayanan, fizik ötesi ya da manevi unsurlarla temas kurulduğuna inanılan dinsel davranış şekli olduğunu ifade etmiştik. İslam bağlamında düşündügüüüzde, abdest, namaz, oruç, hac ve kurban gibi ibadetlerin ritüel için tanımlanan bütün hususları içinde barındırdığı görülür. İslam tarihinde ameli mezhepler adıyla ibadetlerin kesin kurallarını ve sergileniş şekillerini açıklayan güçlü gelenekler inşa edilmiştir. Bu durumda ritüel olan ile ibadet olan arasındaki farkı hangi açıdan derinleştirmek mümkündür? Kurban örneğinde olduğu gibi, kurbanlık hayvanın kesim yerine nasıl getirileceği, nasıl boğazlanacağı, nasıl paylaştırılıp nasıl tüke- 
tileceği gibi sıralı ve katı düzenlemeler açısından baktığımızda, İslam geleneğindeki kurban ibadeti ile pagan Yunan-Roma geleneğinin kurban ritüelini nasıl ayrıştırabiliriz?

Râgıb el-İsfahani, "ibadet" ile "ubudiyet" kavramlarını tanımlarken bu iki kavramı birbirleriyle kıyaslayarak "ubudiyet" in tezellül göstermek, boyun eğmek; "ibadet" in ise tezellül etmenin nihai noktası olarak ilkinden daha mübalağalı bir tanım içerdiğine işaret etmektedir. Ayrıca kelimenin "abd" köküne işaret edilerek "kul" anlamında kullanıldığ 1 ayetlerle örneklendirilmiştir. ${ }^{19}$ Genel olarak sözlüklerde "boyun eğme, alçak gönüllülük, itaat, kulluk ve tapmatapınma" anlamlarına gelen "ibadet" dini bir terim olarak insanın Allah'a sayg1, sevgi ve itaatini göstermek, onun hoşnutluğunu kazanmak niyetiyle ortaya koyduğu belirli tutum ve davranışları, buna benzer düşünüş, duyuş ve sözleri ifade eder. Ancak kelimenin dini içerikli belli ve düzenli davranış biçimleri için kullanımı daha yaygindır. ${ }^{20}$

Kültürel anlamda kelimenin yaygın olarak dini içerikli belli ve düzenli davranış biçimleri ile tanımlanması, İslami literatürde yer alan ibadet kavramının ritüel kavramı ile benzer davranışlara işaret ettiği sonucunu hasıl etmektedir. Esasen hac ve umre ibadetleri s1rasında yerine getirilen belirli davranışlar anlamında ve fikhî bir terim olan "menasik" ya da namaz gibi bir ibadeti oluşturan ana unsur anlamında ve yine fıkhî terim olan "rükün" kavramları genellikle ritüel bağlamında değerlendirilebilmiştir. Ritüel kelimesinin sadece davranışsal modlar üzerinden tanımlandığını düşünürsek menasik ve rükün unsurlarıyla biçimlendirilmiş ibadetin, ritüel ile kıyaslandığında mitik anlatı değil iman temelinde gerçekleştirildiğine dikkat edilmesi gerekir. Kur'an'ın iki ayeti bu hususu açıklayan güzel örnekler içerir:

"Nihayet hac ibadetlerinizi bitirdiğinizde, bir zamanlar babalarınızı andığınız gibi hatta daha coşkulu bir anışla Allah'ı anın." (Bakara: 200)

İslam, cahiliye dönemi şirk geleneği içinde atalarıyla övünmelerini ve babalarının meziyetlerini sayar döker hale gelerek hatta

19 Bkz. Rağıb el-İsfahanî, Müfredât: Kur'an Kavramları Sözlüğ̈̈, tr.: A. Güneş, M. Yolcu (İstanbul: Çıra Yayınları, 2012), ss. 667-668.

${ }^{20}$ Mustafa Sinanoğlu, "İbadet”, TDV, İslam Ansiklopedisi, c. 19, 1999, s. 233. 
"kabirlerdeki geçmişlerini sayacak" kadar asabiyet ve kavmiyetçilik eğilimi içine girmelerini şiddetle eleştirmektedir. Söz konusu ayete dair müfessirlerin çoğunluğunun görüşüne göre "Cahiliye döneminde Araplar haccı bitirdikten sonra fazilet ve menakiblerini zikretmek suretiyle atalarını övme hususunda çok ileri gitmişlerdir. Cenab-ı Hak, onlara 'atalarınızı anmada çok ileri gittiğiniz gibi Allah'ı anmada da çok mübalağa ediniz; nasıl atalarınızı övmede bütün gayretinizi sarf ediyorsanız, bunun için Cenab-1 Hakk'1 övmede, onun nimetlerini ve lütuflarını açıklamada da bütün gücünüzü ortaya koyunuz' emrinde bulunmuştur." 21

Yukarıdaki ayet örneğinde, atalar ile övünmeyi icra eden davranışlar anlamında cahiliye ritüeli Allah'ın adının anıldığı ibadete dönüştürülmüştür. Allah'ın adının anılması ritüelistik bir davranış modunu iman üzerine inşa edilmiş bir bağlllık ve ibadet durumuna çevirmiştir.

“Onların ne etleri, ne de kanları Allah'a ulaşır. Lâkin ona ulaşan tek şey, kalplerinizde beslediğiniz takvadır." (Hac: 37)

Bu ayet tam olarak bu metinde işlenen kurban perspektifli ritüel uygulaması için güzel bir örnektir. Pagan Yunan-Roma uygulamaları başta olmak üzere pek çok pagan geleneğinde kurban edilerek yakılan hayvanın aromatik dumanı tanrılara kadar ulaşmakta ve onları teskin edici bir etki doğurmaktaydı. Kur'an neredeyse doğrudan bu tür paganist kurban uygulamalarını reddederek kurbanın değerini kurban ritüelindeki şekilsel davranışlar ya da kurban hayvanının hususiyetleri değil müminin takvası yani Allah'a karşı güçlü bir inanç duygusu anlamlı kılmaktadır.

\section{Sonuç}

Ritüel ve ibadet kavramları genel anlamiyla mitolojik ya da dini saiklerle yönlendirilmiş tutum ve davranış hallerini ifade etmektedir. Ritüel, kaynağı itibarıyla mitolojik bir anlatıya dayanmakta ve bu anlatı genellikle tanrılar ile insanlar arasında gerilimli bir ilişkiyi ifade etmektedir. Bu gerilim tanrıların kaprisli, kötü niyetli, cezalandırıcı ve insanların tutumuna göre kendi konumunu belirleyen insanileştirilmiş formundan kaynaklanmaktadır. Dolayısıyla paganist

${ }^{21}$ Fahruddîn er-Razî, Tefsir-i Kebîr: Mefâtîh'ul-Gayb, tr. S. Yıldırım vd. 4. Cilt (Ankara: Akçağ, 1989), s. 532. 
gelenekte insanlar ile tanrı ya da tanrılar arasındaki ritüelistik ilişki oldukça değişkendir. Örneğin tanrıların rızasını elde etmek için onlara kurban sunulacak olması paganist insan için modern perspektiften bakıldığında acı bir durumdur. Ancak asıl sorun, bu korkunç addedilen talebin işletilmesindeki trajik süreçtir. Çünkü bir hayvanın törensel bir uygulamayla ve çok katı kurallar çerçevesinde kurban edilmesi modern insan için trajik özelliğini sürdürmektedir. Bu trajedinin temelinde tanrılar ile insanlar arasında var olduğu düşünülen pragmatik bir ilişki yer almaktadır.

İslami literatürün bir kavramı olan "ibadet"i ritüelden ayıran boyut ise, yine kurban örneğinde olduğu gibi, et ve kanın tanrıya ulaşacağını düşünen trajik boyutun ötesinde, davranışı değil inancı merkeze alan bir durumun sergilenmesidir. İslam geleneğinde de ibadetleri yerine getirmek Müslüman için güç olabilir. Kur'an'da namazın ve haccın zor bir ibadet olduğu ifade edilmiştir. Ancak İslami bağlamda bu ibadetlerin ritüele dönüştürülüp bir trajedinin konusu haline getirmekten koruyan unsur Allah'a dönük inanç boyutudur. Paganist geleneğin ritüeli ile İslami kavram olan ibadet arasındaki davranışsal benzerliği yıkıma uğratan etken budur.

Seküler zihin çerçevesinden bakıldığında, kurbanlık hayvanın ilahi bir emre matuf olarak kesilmesi, kurban hayvanı lehine etik bir sorun doğurmaktadır. Ancak bu bakış açısında kurban takdiminin paganist bir ritüel temelinde anlamlandırıldığ 1 ve Burkert'ın tezi bağlamında tanrıyı teskin edici bir gözden çıkarma olarak görüldüğü anlaşılmaktadır. Dolayısıyla İslam ibadet geleneğinde güçlü bir yeri olan kurban takdimesine yönelik seküler eleştiri, esasen kendisine ritüel konusu olan kurban sunumunu referans almaktadır. Bu seküler yaklaşımda göz ardı edilen, ritüele ibadet özelliği kazandıran kulluk ve takva kavramları çerçevesinde kurban sunumunun paganist bir ritüel değil "rabbe yaklaşmak" anlamında bir kulluk bilincine matuf olduğu hususudur.

\section{Kaynakça}

"Ritual", A Dictionary of Sociology, ed.: J. Scott, G. Marshall (Oxford: Oxford University Press, 2009).

Ray A. Rappaport, Ritual and Religion in the Making of Humanity (Cambridge: Cambridge University Press, 1999). 
E. M. Zuesse, “Ritual”, Encyclopedia of Religion (New York: Macmillan, 1987).

Victor Turner, Forest of Symbol (Ithaca: Cornell University Press, 1967).

Jan N. Bremmer, Greek Normative Animal Sacrifice, A Companion to Greek Religion, ed.: D. Ogden (Oxford: Blackwell, 2007).

R. M. Ogilvie, The Romans and their Gods (London: Hogarth Press, 1986).

Ingvild Sælid Gilhus, Animals, Gods and Humans (London: Roudletge, 2006).

Detienne, M. and J.-P. Vernant (eds), The Cuisine of Sacrifice among the Greeks (Chicago: University of Chicago Press, 1989).

P. Garnsey, Food and Society in Classical Antiquity (Cambridge: Cambridge University Press, 1999).

Kevin J. Wetmore, Jr., The Athenian Sun in an African Sky: Modern African Adaptations of Classical Greek Tragedy (London: McFarland \& Company, 2002).

Sarah Dewar-Watson, Tragedy: A Reader's Guide to Essential Criticism (London: Palgrave Macmillan, 2014).

Walter Burkert, Greek Tragedy and Sacrificial Ritual (Duke University, 1966).

Understanding Religious Sacrifice: A Reader, ed.: J. Carter (London: Continuum, 2006).

Walter Burkert, "Ritual in Ancient Greece", Savage Energies: Lessons of Myth and Ritual in Ancient Greece, tr. P. Bing (Chicago: University of Chicago Press, 2001).

Soren Kierkegaard, Korku ve Titreme, tr. İ. Kapaklıkaya (İstanbul: Anka, 2002).

Rağıb el-İsfahanî, Müfredât: Kur'an Kavramları Sözlü̈̆̈̈, tr.: A. Güneş, M. Yolcu (İstanbul: Çıra Yayınları, 2012).

Mustafa Sinanoğlu, "İbadet”, TDV, İslam Ansiklopedisi, c. 19, 1999.

Fahruddîn er-Razî, Tefsir-i Kebîr: Mefâtîh'ul-Gayb, tr. S. Yıldırım vd. 4. Cilt (Ankara: Akçă̆, 1989). 